\title{
Rechargeable Solid Electrolyte Cells with Copper Ion Conductor and Vanadium-Tungsten Complex Oxide
}

\author{
Katsumi KUWABARA*, Jun KUSAGA and Kohzo SUGIYAMA ${ }^{\dagger}$ \\ Received January 8, 1990 ; Accepted March 15, 1990
}

\begin{abstract}
A rechargeable solid electrolyte cell has been developed using a high copper ion conductor, $\mathrm{Rb}_{4} \mathrm{Cu}_{16} \mathrm{I}_{7} \mathrm{Cl}_{13}$, a copper anode, and a vanadium-tungsten complex oxide cathode, $\left(\mathrm{WV}_{2}\right)_{2} \mathrm{O}_{15}$. The open circuit voltage was $0.57 \mathrm{~V}$ at $25^{\circ} \mathrm{C}$. Ten microamperes were gained from the cell at ambient temperature without appreciable polarization. The charge-discharge performance was good, and the cell voltage was held at a level higher than $0.50 \mathrm{~V}$ during 500 or more cycles. The fine rechargeability of the cell was attributed to the use of the complex oxide with Wadsley-Roth type open structure.
\end{abstract}

\section{INTRODUCTION}

Considerable interest has been attracted in the field of rechargeable cells which are useful for driving electronic devices working at very low current density. Among them, solid electrolyte cell systems are promising for such devices because they have long shelf-life stability and have no problem of leakage after prolonged storage at ambient temperature. Studies of practical solid electrolyte cells were begun in 1950 's. In the age, AgI was exclusively used for the solid electrolyte, and $\mathrm{S}$ and $\mathrm{I}_{2}$ were employed as cathode materials so as to form a single shot battery or long life battery 1,2). Afterward, the performance of cells with various silver ion conductors was examined using cathode materials such as $\mathrm{I}_{2}$ and $\mathrm{MeNI}_{5}{ }^{3-5}$ ).

Studies on solid electrolyte cells other than silver cells are also prosperous. Intense attention has been paid to solid state lithium batteries. A cell with LiI was practically developed for the power source of heart pace-maker, in which a charge transfer complex acted as the best

\footnotetext{
* Department of Applied Chemistry, Faculty of Engineering, Nagoya University, Furo-cho, Chikusa-ku, Nagoya 464

Key Words: Rechargeable cell, Solid electrolyte cell, $\mathrm{Rb}_{4} \mathrm{Cu}_{16} \mathrm{I}_{7} \mathrm{Cl}_{13},\left(\mathrm{WV}_{2}\right)_{2} \mathrm{O}_{15}$
}

cathode ${ }^{6)}$. A composite lithium ion conductor in the $\mathrm{LiI}-\mathrm{Al}_{2} \mathrm{O}_{3}$ system was reported as the electrolyte of a lithium cell with mixture cathode of $\mathrm{PbI}_{2}, \mathrm{PbS}$, and $\left.\mathrm{Pb} 7\right) . \mathrm{MnO}_{2}$ and $\mathrm{TiS}_{2}$ were shown to act as the excellent cathode materials of all solid state or solid thin film secondary lithium cell 8,9). Recently, various secondary lithium cells with solid polymer electrolytes (SPE) have been reported extensively 10-15). However, the performance of the cells is not always so good at ambient temperature, since ionic conductivities of SPE are not yet so high as those of electrolyte solutions.

One excellent solid electrolyte of the highest ionic conductivity at room temperature was found in the $\mathrm{RbCl}-\mathrm{CuI}-\mathrm{CuCl}$ system 16-19). Several rechargeable cells with the copper ion conductor were developed by using cathode materials such as transition metal chalcogenides and copper Chevrel phase 20-22). Quite recently, ionic conductor sheets were made with the aid of organic binder and synthetic fiber to expand the application of the solid electrolyte 23 ), and the rehargeable battery was reported using the paper form solid electrolyte and copper Chevrel electrodes 24). We have been searching transition metal compounds for the cathode materials in order to develop all-solid-state cells and have found some good oxides $\mathrm{MnO}_{2}, \mathrm{~V}_{2} \mathrm{O}_{5}$, and 
$\mathrm{WO}_{3}{ }^{25,26)}$. These compounds, however, did not show the characteristics suitable for secondary cells. In the recent paper 27), we have developed a cell with $\mathrm{V}_{6} \mathrm{O}_{13}$ and have shown that the oxide containing crystallographic cavity is a possible cathode material for rechargeable copper cells.

We are able to expect that the cavity concentration in vanadium oxides may be changed by substituting elements with higher valency for vanadium. The class of compounds known as Wadsley-Roth phases affords many chemically similar compounds with different types and amounts of crystallographic shear 28). We have examined complex oxides in the V-Cr-O, V-Mo-O, and V-W-O systems as cathode active materials. The complex oxide containing chromium is troublesome for preparation and poisonous, while the complex oxide with molybdenum showed the cathode behavior somewhat lower than that of the complex oxide with tungsten. This paper describes the possibility of the vanadium-tungsten complex oxide for the rechargeable copper cell.

\section{EXPERIMENTAL}

\subsection{Preparation of solid electrolyte}

The copper ion conductor, $\mathrm{Rb}_{4} \mathrm{Cu}_{16} \mathrm{I}_{7} \mathrm{Cl}_{13}$, was prepared by the method reported by Takahashi et al 17). The appropriate amounts of $\mathrm{RbCl}, \mathrm{CuI}$, and $\mathrm{CuCl}$ were ground and mixed by using a planettype ball mill. After removing toluene used as dispersing reagent, the powder was pressed under a pressure of $300 \mathrm{MPa}$ to form sample pellets which were heated at $200^{\circ} \mathrm{C}$ in an evacuated Pyrex tube and annealed at $130^{\circ} \mathrm{C}$.

\subsection{Anode and cathode materials}

The anode active material was copper powder which was purified in flowing hydrogen gas at $150^{\circ} \mathrm{C}$. The powder was mixed with the solid electrolyte (1:1 in weight) immediately before assembling cells.

Vanadium-tungsten oxides were prepared in the following manner. Commercial grade $\mathrm{V}_{2} \mathrm{O}_{5}$ and $\mathrm{WO}_{3}$ were weighed in mole ratios $1: 2,1: 1$, and 2:1. After mixing the powders in ball mill, pellets were formed under $200 \mathrm{MPa}$ and heated at $650^{\circ} \mathrm{C}$ for $24 \mathrm{~h}$. The products were identified by powder X-ray diffraction. The complex oxides were mixed with the solid electrolyte and graphite powder (IC sample) in the same procedure as in the previous paper 25 ).

\subsection{Galvanic cells}

Solid state galvanic cells ( $13 \mathrm{~mm}$ diam and 3 $\mathrm{mm}$ thick) were formed by the same way as in the early study 29). The electromotive force (e.m.f.) and the polarization were measured in a usual manner. The constant load and constant current discharge behavior was examined to evaluate the performance of the test cells at ambient temperature. The charge-discharge cycling tests were carried out at a current of $10 \mu \mathrm{A}$.

\section{RESULTS AND DISCUSSION}

\subsection{Apparent polarization behavior}

The polarization behavior was obtained for cells with three complex oxides, $(\mathrm{WV})_{2} \mathrm{O}_{10}$ $\left(\mathrm{WV}_{2}\right)_{2} \mathrm{O}_{15}$, and $\left(\mathrm{WV}_{4}\right)_{2} \mathrm{O}_{25}$. Figure $1, \mathrm{~A}$ shows the polarization curve of the cell with $\left(\mathrm{WV}_{2}\right)_{2} \mathrm{O}_{15}$ The curves of the cells with two other oxides were closely similar to the curve shown in Fig. 1, A and independent of the composition of the complex oxides. The cell voltages plotted in the figure were measured immediately after passing current which was held at each level for $30 \mathrm{~s}$ and was stepwise increased. Strictly speaking, observed cell voltages were not equilibrium values except for the value of e.m.f. $0.57 \mathrm{~V}$ at $25^{\circ} \mathrm{C}$. Therefore, the polarization curve must be regarded as an apparent polarization curve of the cell. Such an experimental procedure is, however, quite convenient for instant evaluation of cathode materials and/or the composition of the cathode mixture 25). The apparent polarization performance in this study was superior to that of the cells containing binary metal oxides such as $\mathrm{MnO}_{2}, \mathrm{~V}_{2} \mathrm{O}_{5}$, and $\left.\mathrm{V}_{6} \mathrm{O}_{13} 25,27\right)$. Thus, the complex oxide $\left(\mathrm{WV}_{2}\right)_{2} \mathrm{O}_{15}$ was exclusively used as the cathode active material in the following experiments.

Figure 1, B indicates the curve measured after $24 \mathrm{~h}$ of the first apparent polarization test (Fig. 1, A). It is clear that profiles of the two 
curves are very similar with each other although the voltage at the second operation is fairly low. The fact that the starting voltage of the curve $B$ was lower than that of the curve $A$ suggests that copper ions migrated deeply into the cathode active material at the first operation could not always easily return from the cathode to the electrolyte if the inverse voltage was not applied. On the other hand, the similarity of the shape of both curves suggests that the complex oxide at the starting point of the second operation had the capacity to accommodate copper ions further.

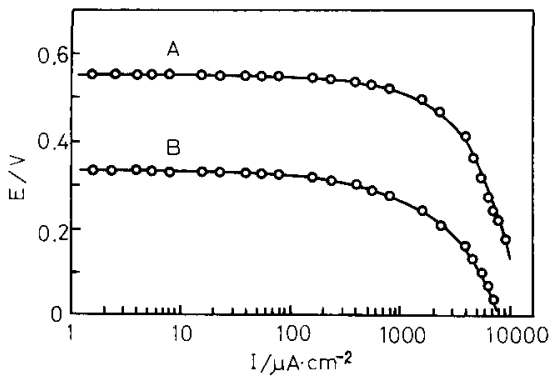

Fig. 1 Apparent polarization behavior of the cell with complex oxide $\left(\mathrm{WV}_{2}\right)_{2} \mathrm{O}_{15}$ at ambient temperature.

A: curve obtained at the first polarization test

B: curve obtained at the second test after $24 \mathrm{~h}$ of the first test

\subsection{Constant load and constant current discharges}

The constant load discharge test was performed by using four loads $1,10,20$, and $50 \mathrm{k} \Omega$. Table 1 shows several data which were obtained at the cut-off voltage $0.52 \mathrm{~V}$. The average current was calculated from the midpoint value of both initial and cut-off voltages and the corresponding load, ignoring the cell own resistance. The discharge result at $50 \mathrm{k} \Omega$ suggested that the discharge capacity of about $2 \mathrm{mAh}$ was possible at the current of about $10 \mu \mathrm{A}$. The efficiencies of both electrodes were obtained on the basis of the capacities estimated from the active material weights and the following reaction

$$
\begin{aligned}
\left(\mathrm{WV}_{2}\right)_{2} \mathrm{O}_{15}+\mathrm{xCu}^{+}+\mathrm{xe}^{-} \rightarrow & \mathrm{Cu}_{\mathrm{x}}\left(\mathrm{WV}_{2}\right)_{2} \mathrm{O}_{15} \\
& (0<\mathrm{x} \leqq 1)
\end{aligned}
$$

( $84 \mathrm{mAh}$ for anode and $6.6 \mathrm{mAh}$ for cathode). The cathode efficiency of about $30 \%$ could be taken at $50 \mathrm{k} \Omega$ load.
Table 1 Constant load discharge performance of the cell with the complex oxide $\left(\mathrm{WV}_{2}\right)_{2} \mathrm{O}_{15}$ at ambient temperature.

\begin{tabular}{c|c|c|c|c}
\hline $\begin{array}{c}\text { Load } \\
/ \mathrm{k} \Omega\end{array}$ & $\begin{array}{c}\text { Average } \\
\text { current } \\
/ \mathrm{\mu A}\end{array}$ & $\begin{array}{c}\text { Discharge } \\
\text { capacity } \\
/ \mu \mathrm{\mu h}\end{array}$ & $\begin{array}{c}\text { Anode } \\
\text { efficiency } \\
/ \%\end{array}$ & $\begin{array}{c}\text { Cathode } \\
\text { efficiency } \\
/ \%\end{array}$ \\
\hline 1 & 539 & 135 & 0.16 & 2.05 \\
10 & 54.4 & 326 & 0.39 & 4.94 \\
20 & 26.9 & 1740 & 2.07 & 26.4 \\
50 & 10.9 & 1960 & 2.34 & 29.7 \\
\hline
\end{tabular}

Table 2 Constant current discharge performance of the cell with the complex oxide $\left(\mathrm{WV}_{2}\right)_{2} \mathrm{O}_{5}$.

\begin{tabular}{c|c|c|c}
\hline $\begin{array}{c}\text { Current } \\
/ \mu \mathrm{A}\end{array}$ & $\begin{array}{c}\text { Discharge } \\
\text { capacity } \\
/ \mu \mathrm{Ah}\end{array}$ & $\begin{array}{c}\text { Anode } \\
\text { efficiency } \\
/ \%\end{array}$ & $\begin{array}{c}\text { Cathode } \\
\text { efficiency } \\
/ \%\end{array}$ \\
\hline 10 & 1000 & 1.2 & 15 \\
50 & 100 & 0.12 & 1.5 \\
100 & 47 & 0.056 & 0.71 \\
300 & 43 & 0.051 & 0.65 \\
500 & 30 & 0.036 & 0.45 \\
\hline
\end{tabular}

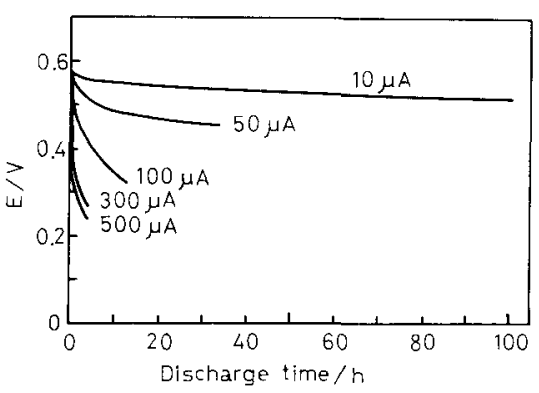

Fig. 2 Constant current discharge performance of the cell with $\left(\mathrm{WV}_{2}\right)_{2} \mathrm{O}_{15}$.

The constant current discharges were carried out at $10,50,100,300$, and $500 \mu \mathrm{A} / \mathrm{cell}$. The performance of the cell is shown in Fig. 2. It can be seen from the figure that the cell is available for low current discharge. The discharge capacity and the electrode utilization efficiencies are listed in Table 2. The discharge capacity at $10 \mu \mathrm{A}$ was 1 $\mathrm{mAh}$ which was nearly half of the value obtained at the constant load of $50 \mathrm{k} \Omega$ (Table 1). This discrepancy seems to be due to the fact that the cell own resistance was ignored at the average current estimation in the constant load experiment. The internal resistance of the cell will be investigated in the near future. As the current or discharge reaction rate increased, the 
electrode efficiencies decreased. It appears from the fact that in the case of high current discharge the reaction predominantly proceeded at the surface of the electrode active materials. Considering that in this work thick tablets for both electrodes were evaluated in order to handle them with ease, the electrode utilization efficiencies will be considerably raised if thin electrode tablets are used.

\subsection{Charge-discharge behavior}

As mentioned above, the apparent polarization performance of the cell with $\left(\mathrm{WV}_{2}\right)_{2} \mathrm{O}_{15}$ was better than that of the cells reported in the previous papers 25,27 ). Because the oxide, $\mathrm{V}_{6} \mathrm{O}_{13}$, is a promising cathode material for rechargeable cell, the complex oxide $\left(\mathrm{WV}_{2}\right)_{2} \mathrm{O}_{15}$ will also have the possibility for the candidate of the cyclable cathode material. Thus, the charge-discharge cycling test was done concerning the cell used for the first apparent polarization experiment. The current passed to the cell was $10 \mu \mathrm{A} /$ cell and the duration of each charge and discharge was 30 min. The cycling was simply carried out without rest. The cell voltage gradually increased from $0.30 \mathrm{~V}$ and reached the initial e.m.f. value of the cell after the cycle number of 50. Then, the discharge end voltage decreased very slowly as the cycling was continued. This result suggested the availability of the complex oxide.

Another cycling test was performed using a virgin cell under the same conditions as in the case mentioned above. Figure 3 shows the representative charge-discharge cycling curves. The form of the curve changed little by little with increase of cycling number. Although the result

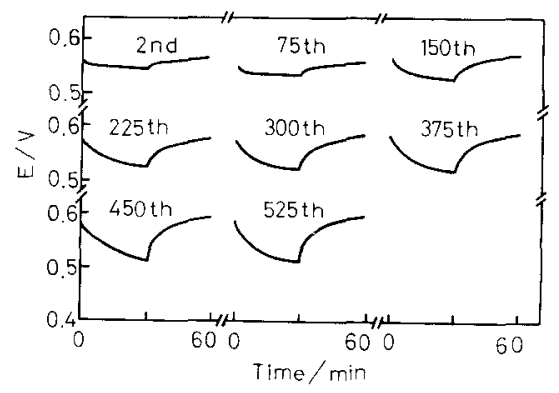

Fig. 3 Representative charge-discharge curves in the course of cycling at $10 \mu \mathrm{A} /$ cell.

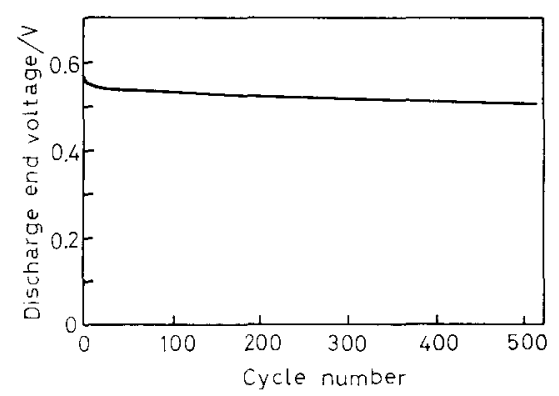

Fig. 4 Discharge end voltage curve illustrating the charge-discharge cycling performance of the cell.

suggested gradual deterioration of the cell, the cell voltage decreased very slowly. The profile of the cell voltage change is shown in Fig. 4 . The discharge end voltage was higher than $0.50 \mathrm{~V}$ even after 500 cycles. Such a cycling performance was the best of all the performance of the cells prepared using oxides.

Since both the anode and the solid electrolyte were the same as those used for the previous cells 26,27$)$, the improvement of the cell performance seems to be owing to the use of the complex oxide, $\left(\mathrm{WV}_{2}\right)_{2} \mathrm{O}_{15}$, as the cathode active material. The vanadium-tungsten complex oxide takes the Wadsley-Roth phase 28). Figure 5 displays idealized structure of the complex oxide. The basic structural units of the phase are blocks consisted of distorted $\mathrm{MO}_{6}$ octahedra sharing corners, which are joined to adjacent blocks either through edge sharing or a combination of edge sharing and

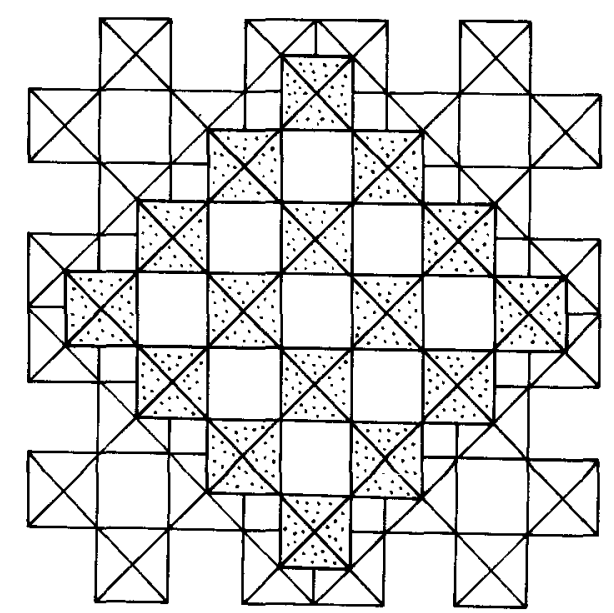

Fig. 5 Idealized crystal structure of the vanadiumtungsten complex oxide $\left(\mathrm{WV}_{2}\right)_{2} \mathrm{O}_{15^{28)}}$. 
tetrahedrally coordinated metal atoms at the block corners. Such structures generally show open tunnel like regions bound by regions of extensive edge sharing ${ }^{30}$ ). In this study, copper ions may be able to easily enter from the electrolyte to the complex oxide through the open tunnel, and on the contrary, copper ions at the charging operation may return with ease from the oxide to the electrolyte by way of the tunnel. The decay curves shown in Fig. 3 include IR drop and other overvoltages. Detailed analyses of the curves were not carried out in this study.

\section{CONCLUSION}

Vanadium-tungsten complex oxides, $(\mathrm{WV})_{2} \mathrm{O}_{10},\left(\mathrm{WV}_{2}\right)_{2} \mathrm{O}_{15}$, and $\left(\mathrm{WV}_{4}\right)_{2} \mathrm{O}_{25}$, were prepared and were used as the cathode active materials in the cells $\mathrm{Cu}, \mathrm{X} / \mathrm{X} / \mathrm{V}-\mathrm{W}-\mathrm{O}, \mathrm{X}, \mathrm{C}$, where $\mathrm{X}$ was copper ion conductor $\mathrm{Rb}_{4} \mathrm{Cu}_{16} \mathrm{I}_{7} \mathrm{Cl}_{13}$ and $\mathrm{C}$ was graphite. The three oxides showed almost the same cathode behavior in apparent polarization curves.

Both constant load and constant current discharges using the complex oxide $\left(\mathrm{WV}_{2}\right)_{2} \mathrm{O}_{15}$ indicated the cell capacity of about $1 \mathrm{mAh}$ at a current of $10 \mu \mathrm{A} /$ cell without significant drop of the working voltage. Although the cathode utilization efficiency calculated from the amount of the complex oxide was low, i.e. about $15 \%$ at $10 \mu \mathrm{A}$ discharge, this value will be raised by making thinner cathode layer. The cycling performance was the best of all the cells with oxide cathodes so far examined, and the cell voltage was kept higher than $0.50 \mathrm{~V}$ even after 500 cycles. Such high performance seems to originate in the cathode improvement by using the complex oxide with open tunnel structure.

\section{REFERENCES}

1) K. Lehovec and J.Broder, J. Electrochem. Soc., 101,208 (1954).

2) J. L. Weininger, J. Electrochem. Soc., 106, 475 (1959).

3) T. Takahashi and O. Yamamoto, Electrochim. Acta, 11, 779 (1966).

4) B. B. Owens, J. S. Sprouse and D. L. Warburton, Proceedings 25th Annual Power Sources Conference, p. 8, Atlantic City, N.J. (1972).
5) B. B. Owens, B. K. Patel, P. M. Skarstad and D. L. Warburton, Solid State Ionics, 9 \& 10, 1241 (1983).

6) A. A. Schneider, W. Greatbach and R. Mead, Power Sources, 5, 651 (1975).

7) C. C. Liang and L. H. Barnette, J. Electrochem. Soc., 123, 453(1976).

8) M. Kanda, S. Yamada, T. Shirogami, Y. Sato and T. Takamura, J. Appl. Electrochem., 12, 599 (1982).

9) K. Kanehori, K. Matsumoto, K. Miyauchi and T. Kudo, Solid State Ionics, 9 \& 10, 1445 (1983).

10) A. Hooper and J. M. North, Solid State Ionics, 9 \& 10,1161 (1983).

11) P. Novak, O. Inganas and R. Bjorklund, $J$. Electrochem. Soc., 134, 1341 (1987).

12) F. Bonino, M. Ottaviani and B. Scrosati, J. Electrochem. Soc., 135, 12 (1988).

13) M. Z. A. Munshi and B. B. Owens, Solid State Ionics, 27, 251 (1988).

14) K. M. Abraham, M. Alamgir, and S. J. Perrotti, J. Electrochem. Soc., 135, 535 (1988).

15) Z. Ogumi, Y. Uchimoto, Z. Takehara and $Y$. Kanamori, J. Electrochem. Soc., 135, 2649 (1988).

16) T. Takahashi, O. Yamamoto, $S$. Yamada and $S$. Hayashi, J.Electrochem. Soc., 126, 1654 (1979).

17) T. Takahashi, R. Kanno, Y. Takeda and $O$. Yamamoto, Solid State Ionics, 3 \& 4, 283 (1981).

18) S. Geller, J. R. Akridge and S. A. Wilber, Phys. Rev., B19, 5396 (1979).

19) K. Nag and S. Geller, J. Electrochem. Soc., 128, 2670 (1981).

20) R. Kanno, Y. Takeda, M. Imura and O. Yamamoto,J.Appl.Electrochem., 12,681 (1982).

21) R. Kanno, Y. Takeda, Y. Oda, H. Ikeda and O. Yamamoto, Solid State Ionics, 18 \& 19, 1068 (1986).

22) R. Kanno, Y. Takeda, M. Ohya and $O$. Yamamoto, Mat.Res.Bull., 22, 1283 (1987).

23) K. Takada, T. Kanbara, T. Sotomura and $S$. Kondo, Extended Abstracts of 14th Symposium on Solid State Ionics in Japan, p. 93, Tottori (1987).

24) T. Sotomura, Y. Moriwaki, S. Kondo and T. Iwaki, Extended Abstracts of 40th ISE Meeting, p. 1260, Kyoto (1989).

25) K. Kuwabara, K. Hanafusa and K. Sugiyama, $J$. Appl.Electrochem., 18, 705(1988).

26) K. Kuwabara, K. Hanafusa and K. Sugiyama, $J$. Electrochem. Soc., 136, 319 (1989).

27) K. Kuwabara, A. Kondo and K. Sugiyama, Denki Kagaku, 57, 548 (1989).

28) R. J. Cava, D. W. Murphy and S. M. Zahurak, J. Electrochem. Soc., 130, 2345(1983).

29) T. Takahashi, K. Kuwabara, M. Miura and M. Nakanishi, J. Appl.Electrochem., 12, 213 (1982).

30) R. J. Cava, D. W. Murphy and S. M. Zahurak, $J$. Electrochem. Soc., 130, 243 (1983). 